\title{
Extension of the vase life of Lilium pumilum cut flowers by pulsing solution containing sucrose, citric acid and silver thiosulfate
}

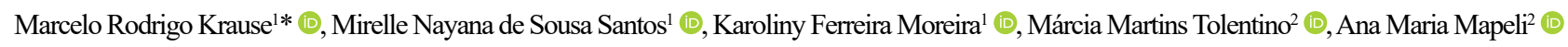 \\ ${ }^{1}$ Universidade Federal de Viçosa, Departamento de Agronomia, Viçosa - MG, Brazil. \\ ${ }^{2}$ Universidade Federal do Oeste da Bahia, Centro de Ciências Biológicas e Saúde, Barreiras - BA, Brazil.
}

\begin{abstract}
Floriculture is a promising activity and has great economic importance. In this context, the cultivation of Lilium pumilum Redouté stands out. However, one of the main challenges flower farmers face is that a large part of the products is lost before reaching the final consumer, due to postharvest losses. Such losses can be minimized by adopting some techniques, such as the use of conditioning solution (pulsing), which has been effective in preventing early senescence. In this sense, this study aimed to evaluate the effect of pulsing with sucrose, citric acid and silver thiosulphate on postharvest conservation of L. pumilum cut flowers. All treatments promoted a $1.8 \pm 0.3$ day increase in longevity, uniformity of floral opening, and reduced fresh weight loss compared to the control (flowers that were not pulse-treated). There was no significant difference in chlorophyll content and leaf relative water content. The time of exposure to pulsing caused significant differences in the reduction of anthocyanin contents when compared to the control, demonstrating that pulsing preservative solution for at least $6 \mathrm{~h}$ extends the vase life of $L$. pumilum cut flowers by two days.
\end{abstract}

Keywords: postharvest losses; preservative solution; pulsing.

\section{Resumo}

Aumento da vida de vaso de flores de corte de

Lilium pumilum por solução pulsante contendo sacarose, ácido cítrico e tiossulfato de prata

A floricultura é uma atividade promissora e de grande importância econômica. Neste contexto, o cultivo de Lilium pumilum Redouté vem recebendo destaque. Contudo, uma das dificuldades enfrentadas pelos floricultores é que grande parte dos produtos se perde antes de chegar ao consumidor, devido às perdas pós-colheita. Tais empecilhos podem ser revertidos por meio de técnicas adequadas, como é o caso do uso de solução de condicionamento (pulsing), a qual tem sido eficaz no controle da senescência precoce. Diante disso, esse estudo teve como objetivo avaliar a influência da solução via pulsing de sacarose, ácido cítrico e tiossulfato de prata sobre a conservação pós-colheita de hastes florais de L. pumilum. Todos os tratamentos promoveram aumento de $1.8 \pm 0.3$ dias na longevidade, uniformização da abertura floral e menor perda de massa fresca em relação ao controle. Não houve diferença significativa nos teores de clorofila e no teor relativo de água da folha. O tempo de exposição ao pulsing ocasionou diferenças significativas na redução dos teores de antocianina quando comparado ao controle, demonstrando que o uso de solução preservativa aplicada a partir de $6 \mathrm{~h}$, em pulsing, proporciona aumento da vida de vaso para o L. pumilum.

Palavras-chave: perdas pós-colheita; soluções preservativas; pulsing.

\section{Introduction}

The ornamental plant market differs from other agribusiness sectors for its constant investments on the improvement of desirable commercial characteristics. The interest for species that present flowers of easy propagation, with exuberant coloration, constant production throughout the year and accessible costs to producers and consumers (Moura et al., 2010) is notorious. This segment is growing, and this growth creates an increasingly competitive market, which seeks higher quality products every day (Hummel and Miguel, 2017).

As a result, the production of ornamental plants has been intensified, so that there are several species on the rise. The cultivation of lilies (Lilium spp.) has been highlighted,

*Corresponding author: agro.krause@gmail.com 
since it responds to market interests (Fu et al., 2020), especially Lilium pumilum Redouté, a species that presents easy reproduction, heights varying from 30 to $50 \mathrm{~cm}$ and numerous smooth and linear leaves. However, the species is also suitable for cut flowers, emphasizing the importance of postharvest preservation to lengthen its vase life.

Although production and commercialization of cut flowers have been growing, a large portion of the product is lost before even reaching the retail market, due to postharvest losses, which is intensified by the high perishability of flowers (Gupta and Dubey, 2018). Besides, flowers have their physiological processes altered after harvest: there are reductions in water absorption rate, depletion of respiratory substrates, increased ethylene biosynthesis, acceleration of senescence, as well as vascular blockage of cut stems by fungal and bacterial infection (Sant'anna et al., 2010).

However, such problems can be minimized by techniques that extend the vase life of cut flowers and, consequently, the period of commercialization, providing high-quality flowers (Zhao et al., 2018). Among these techniques, preservative solutions stand out, since they can be used throughout the production chain, from production to final consumer (Menegaes et al., 2019).

The application of sucrose is one of the techniques used to extend the vase life of cut flowers, as it supplies the flower with adequate substrates for respiration. Sucrose can be applied through pulsing, which corresponds to a rapid pre-transport or pre-storage treatment, in which freshly harvested flowers are placed in a solution specially formulated to extend their storage and vase life (Almeida et al., 2011). Pulsating solutions can be antibacterial agents. These solutions reduce the problem of vascular obstruction (physiological xylem blockage) due to the proliferation of bacteria at the base of the flower stem and, associated with better maintenance of water absorption, prolong the vase life of cut flowers (Liu et al., 2012).

Lilies are highly sensitive to the hormone ethylene, which plays an important role in the acceleration of abscission, senescence and premature death of floral buds, resulting in tissue deterioration and reduced postharvest life (Azuma et al., 2020; Sidhdharth and Nivethaa, 2020). The physiological effects of ethylene can be reduced by inhibitors of its biosynthesis or actions. The silver ion $\left(\mathrm{Ag}^{+}\right)$ is an ethylene-action inhibitor that can be applied in the form of silver nitrate $\left(\mathrm{AgNO}_{3}\right)$ or silver thiosulfate $\left[\mathrm{Ag}\left(\mathrm{S}_{2} \mathrm{O}_{3}\right)_{3}^{-3}\right]$ (STS). It blocks the action of $\mathrm{C}_{2} \mathrm{H}_{4}$ by competing for the binding sites of ethylene receptors (Lima et al., 2017). The use of this preservative solution has increased considerably in floriculture, since it has been very effective in controlling senescence, delaying the effects on the respiratory and transpiration rates, as well as in the production of ethylene (Liu et al., 2018; Sedaghathoor et al., 2020).

It is expected that sucrose, citric acid and STS may be effective ingredients in pulsing preservative solutions, in order to extend the longevity of Lilium pumilum Redouté cut flowers. In this combination, sucrose provides energy to flowers, citric acid reduces the $\mathrm{pH}$, therefore inhibiting microbial proliferation, and STS suppresses the action of ethylene (Bellé et al., 2004).

Although the vase life extension of L. pumilum flowers maintained in preservative solutions containing sucrose, citric acid, and STS (Santos and Mapeli, 2015) has already been demonstrated, there is no report on the influence of pulsing with these substances on the vase life of L. pumilum flowers. This study aimed to evaluate the effect of pulsing solution (sucrose, citric acid and STS) on postharvest conservation of L. pumilum cut flowers.

\section{Material and Methods}

Lily flowers (L. pumilum Redouté) were supplied by flower growers from Brasília, Brazil. The plant, still potted, was acclimatized in a cold room $\left(5^{\circ} \mathrm{C}\right)$ for 12 -h. After this process, stems with flowers at S0 (green floral bud) and S1 (bud showing the first petal color) (Santos et al., 2018) stages were cut - leaving only one flower bud and leaves - with a standardized length of $25 \mathrm{~cm}$, in the absence of mechanical damage and pathogens. The cut stems were then placed in pulsing solutions containing sucrose $\left(20 \mathrm{~g} \mathrm{~L}^{-1}\right)$, citric acid $\left(100 \mathrm{mg} \mathrm{L}^{-1}\right)$ and silver thiosulfate (STS, $0.2 \mathrm{mM}$ ), at pH 3.6, at 0, 6-, 12-, 18- and 24-h (Santos and Mapeli, 2015). The experimental design was completely randomized, with four replicates, with two stems holding two buds per experimental unit.

The experiment was conducted at an air temperature of 25 ${ }^{\circ} \mathrm{C}$, relative humidity of $50 \%-70 \%$, and light intensity of $7-10$ $\mu \mathrm{mol} \mathrm{m} \mathrm{m}^{-2} \mathrm{~s}^{-1}$.After the pulse treatment, the cut stems were placed in vases containing distilled water. Every two days, the water was renewed and the base $(1 \mathrm{~cm})$ of the stems was cut. The cut stems remained in the vessel until the beginning of senescence.

The vase life of the cut flowers, i.e. the number of days between the harvest and the time of loss of commercial quality (Barbosa et al., 2005) was evaluated daily. Floral opening was also determined daily from visual changes in development stages, being classified as follows: - S0: green floral bud;

- S1: floral bud at the beginning of orange coloration;

- S2: orange floral bud;

- S3: semi-open flower;

- S4: open flower;

- S5: senescent flower (Santos et al., 2018).

In addition, the volume of water uptake was evaluated every two days, and the fresh mass loss was determined by daily weighting of the samples. The chlorophyll content was evaluated by the Minolta SPAD chlorophyll meter (Konica Minolta Inc., Tokyo, Japan), in the basal and apical part of three leaves of each stem. The relative water content was determined at the end of the pulsing treatment and then every three days, according to the method of Catsky (1974). The anthocyanin content was measured at the end of the pulsing treatment and then every three days (Fuleki and Francis, 1968).

The data was submitted to analysis of variance and the averages were compared using Tukey's test at a 5\% probability level. The procedures were performed using the Sisvar 5.6 software, adopting an $\alpha$ of 0.05 (Ferreira, 2019).

\section{Results and Discussion}

The vase life of $L$. pumilum flower was extended by treatment with the preservative solution, with an average 
extension of $1.8 \pm 0.3$ days (Figure 1A). While the control had a vase life of $10.6 \pm 0.4$, the treatments with pulsing had a vase life of $12.4 \pm 0.3$ days. It is worth mentioning that the pulse treatment of $6 \mathrm{~h}$ was sufficient to extend vase life by approximately 2 days $(p<0.05)$; therefore, the flower stems do not need to remain consecutively in the solution, which would require greater labor and cost without improving in quality and vase life.

These beneficial results are associated with STS, ethylene-action inhibitor, which is efficient in reducing the deterioration related to this hormone (Dar and Tahir, 2018). Simultaneously, the water balance of the cut stem is maintained by sucrose, because it accumulates inside the flower, increasing the concentration of osmotically active solutes and, consequently, maintaining petal turgidity (Pivetta et al., 2018); while citric acid reduces the proliferation of the bacteria population in the preservative solution and increases the water conductance in cut flower xylem (Amin, 2017). Cut rose (Rosa hybrida cv. 'High \& Magic') treated with $125 \mathrm{mg} \mathrm{L}^{-1}$ silver nanoparticles for $2 \mathrm{~h}$ and placed in vases with sucrose $(2 \%)$ showed an increase in vase life of approximately four times (14 days) when compared to nontreated flowers (Alkasir et al., 2017). The beneficial effect of citric acid $\left(200 \mathrm{mg} \mathrm{L}^{-1}\right)$ associated with sucrose $(4 \%)$ was also evidenced in Lilium longiflorum by Dias-Tagliacozzo et al. (2005), who obtained a 2-day extension in vase life when pulsing the flowers for $24 \mathrm{~h}$.
In the current study, it was verified that, regardless of the time that the flower stems remained in the pulsing solution, no significant variation was observed in the floral opening percentage $(\mathrm{p}<0.05)$, and the average value was $86.1 \%$ (Figure 1B). Similar results were found by Bellé et al. (2004), when evaluating the effect of STS $(0.077$ $\mathrm{mM}$ ) and sucrose (2\%), supplied via pulse treatment, on the conservation of chrysanthemum flowers (Dendranthema grandiflora Tzvelev. 'Bronze Repin'). However, in tests with $4 \%$ sucrose and $200 \mathrm{mg} \mathrm{L}^{-1}$ citric acid solution pulsed for $24 \mathrm{~h}$ in L. longiflorum cut flowers, Dias-Tagliacozzo et al. (2005) obtained uniformity of the floral opening, which was not observed in other treatments.

Regarding the chlorophyll content, a reduction in the SPAD index was observed in the 12th day after harvest for all pulsing times $(0,6,12,18$ and $24 \mathrm{~h})$ when compared to the other days $(\mathrm{p}<0.05)$. When comparing treatments, the floral stems held in the solution for $24 \mathrm{~h}$ presented SPAD indices lower than the control flowers only in the 12th day $(p<0.05)$. These results (Table 1$)$ differ from those found by Dias-Tagliacozzo et al. (2005), who verified that the green color of $L$. longiflorum leaves lasted for five days for both pulse-treatment ( $24 \mathrm{~h}$ with $4 \%$ sucrose and $200 \mathrm{mg} \mathrm{L}^{-1}$ citric acid) and nontreated flowers.

There were differences in water uptake between the control and the other treatments after pulsing. Flowers
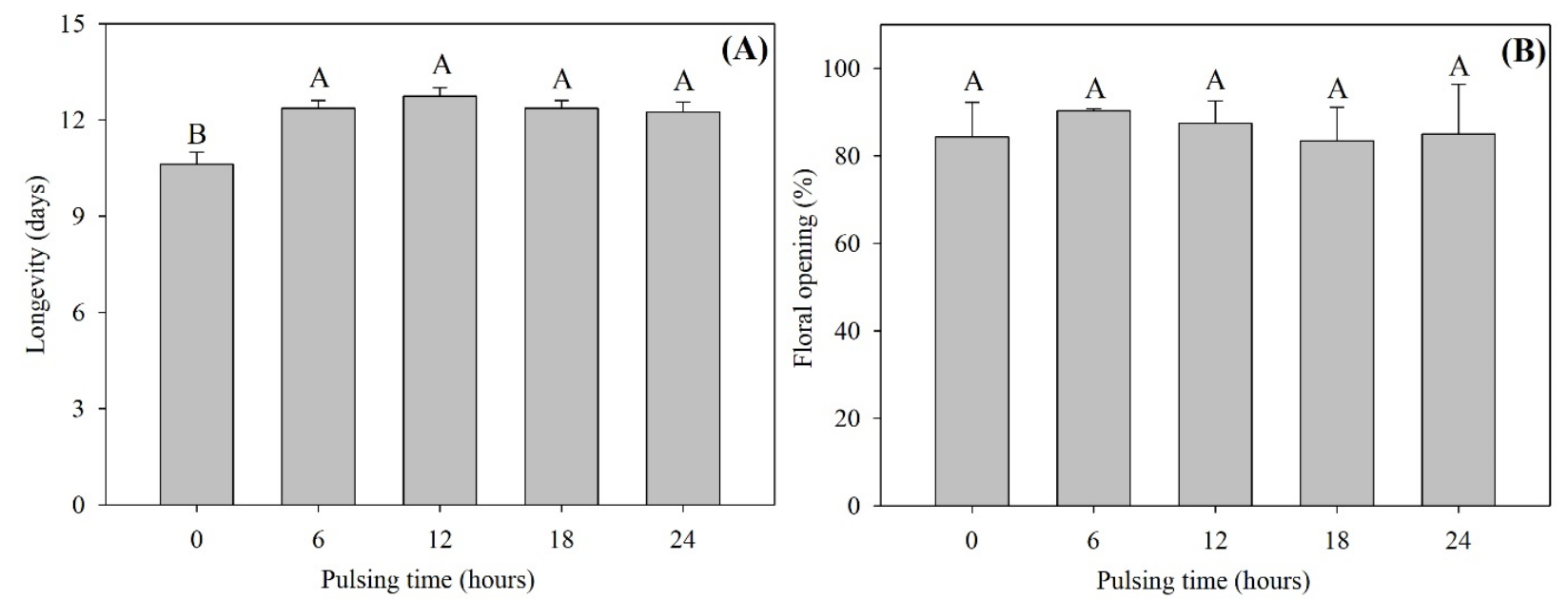

Figure 1. (A) Vase life and (B) floral opening of Lilium pumilum flowers pulse-treated with sucrose (sucrose $20 \mathrm{~g} \mathrm{~L}^{-1}$ ), citric acid $\left(100 \mathrm{mg} \mathrm{L}^{-1}\right)$ and STS $(0.2 \mathrm{mM})$. Data represents the mean \pm standard error $(\mathrm{n}=4)$. Means followed by the same letter do not differ by Tukey's test at 5\% probability level.

Table 1. Chlorophyll content of Lilium pumilum flowers pulse-treated with sucrose $\left(20 \mathrm{~g} \mathrm{~L}^{-1}\right)$, citric acid $\left(100 \mathrm{mg} \mathrm{L}^{-1}\right)$ and silver thiosulfate $(0.2 \mathrm{mM})$ for $0,6,12,18$ and $24 \mathrm{~h}^{*}$.

\begin{tabular}{|l|c|c|c|c|c|}
\hline \multirow{2}{*}{ Pulsing time } & \multicolumn{5}{|c|}{ Total chlorophyll content (SPAD) } \\
\cline { 2 - 6 } & Day 0 & Day 3 & Day 6 & Day 9 & Day 12 \\
\hline $0 \mathrm{hour}$ & $45.4 \pm 0.6 \mathrm{Aa}$ & $45.4 \pm 0.6 \mathrm{Aa}$ & $46.2 \pm 1.0 \mathrm{Aa}$ & $45.1 \pm 0.7 \mathrm{Aa}$ & $41.4 \pm 0.0 \mathrm{Ab}$ \\
\hline $6 \mathrm{~h}$ & $44.9 \pm 1.3 \mathrm{Aa}$ & $44.9 \pm 1.3 \mathrm{Aa}$ & $46.9 \pm 0.6 \mathrm{Aa}$ & $45.4 \pm 0.8 \mathrm{Aa}$ & $39.6 \pm 0.7 \mathrm{ABb}$ \\
\hline $12 \mathrm{~h}$ & $43.1 \pm 1.1 \mathrm{Aa}$ & $43.1 \pm 1.1 \mathrm{Aa}$ & $44.3 \pm 0.8 \mathrm{Aa}$ & $42.1 \pm 1.1 \mathrm{Aab}$ & $38.9 \pm 1.2 \mathrm{ABb}$ \\
\hline $18 \mathrm{~h}$ & $44.7 \pm 0.2 \mathrm{Aa}$ & $44.7 \pm 0.2 \mathrm{Aa}$ & $43.8 \pm 0.9 \mathrm{Aa}$ & $44.5 \pm 0.6 \mathrm{Aa}$ & $37.5 \pm 2.5 \mathrm{ABb}$ \\
\hline $24 \mathrm{~h}$ & $44.2 \pm 0.4 \mathrm{Aa}$ & $44.2 \pm 0.4 \mathrm{Aa}$ & $45.0 \pm 1.3 \mathrm{Aa}$ & $43.9 \pm 0.6 \mathrm{Aa}$ & $35.0 \pm 1.3 \mathrm{Bb}$ \\
\hline
\end{tabular}

*Means followed by the same uppercase letter in the column and lowercase letter in the row do not differ from each other by Tukey's test at $5 \%$ probability level. Data represents the mean \pm standard error $(n=4)$. 
pulse-treated for 6 -h presented $5.8 \% \pm 3.4 \%$ higher water uptake than control flowers at the first day after harvest, while pulsing for 12,18 and 24 hours reduced water uptake by $13.3 \% \pm 3.6 \%, 26.6 \% \pm 6.9 \%$, and $39.2 \% \pm 3.7 \%$, respectively, compared to the control (Figure 2). Regardless of the treatment, the highest uptake occurred on the first day after harvest, after which there was a reduction in uptake.

These results are in line with those observed by Santos et al. (2018) and Alkaç et al. (2020), who demonstrated the highest water uptake rate in the initial days of storage for L. pumilum and dahlia. Among the pulse-treated, it was observed that $6 \mathrm{~h}$ provided better water uptake and, possibly, the pulsing treatment contributed for that (Figure 2). In comparison with the control, even with good water absorption, there was a rapid decline in fresh weight (Figure 3). The stem that remained in the solution for more than 6 hours showed less water absorption; this could be due to higher concentrations of sugar, resulting in some type of phytotoxicity (Sales et al., 2018).

Hydration is an important postharvest factor, since favorable water balance means a good relation between the water transported and the water uptake, which is reflected in the fresh weight of the floral stem. The 6, 12 and 24 hour's pulse treatments decreased weight loss in 3.9, 2.9 and 3.25 times, respectively, when compared to the control (Figure 3).

Preventing the loss in flower fresh weight is desirable from the commercial point of view, in order to avoid the rapid deterioration of the product and maintain its quality. According to Dias-Tagliacozzo et al. (2005), the loss of fresh weight happens because of transpiration processes and the reduction of water conductivity during the senescence of cut flowers. The presence of sucrose in the pulsing solution causes this variation in flower weight loss (Nascimento et al., 2019), probably because sugar is an osmotically active solute, which reduces the osmotic potential, maintaining cell turgor (Van Doorn, 2001). On the other hand, the control flowers lost water at the same time they absorbed it.

Regarding the leaf relative water content, there was no marked decrease in the treatments as compared to the pulsing time (Table 2). During storage, difference for pulsing time on the 9th day was observed when the $6 \mathrm{~h}$ pulse treatment provided lower TRA values when compared to 12,18 , and $24 \mathrm{~h}$.

Given these results (Table 2), it is possible to state that L. pumilum flower stems have high turbidity, which is not easily affected by exposure to certain preservative substances, since these did not affect the water potential of the cells. The excessive loss of fresh weight (water) by transpiration and/or obstruction of the xylem vessels reduce postharvest life.



Figure 2. Volume water uptake (\%) of Lilium pumilum flowers pulse-treated with sucrose (sucrose $20 \mathrm{~g} \mathrm{~L}^{-1}$ ), citric acid $\left(100 \mathrm{mg} \mathrm{L}^{-1}\right)$ and STS $(0.2 \mathrm{mM})$ at different times.

Data represents the mean \pm standard error $(n=4)$.

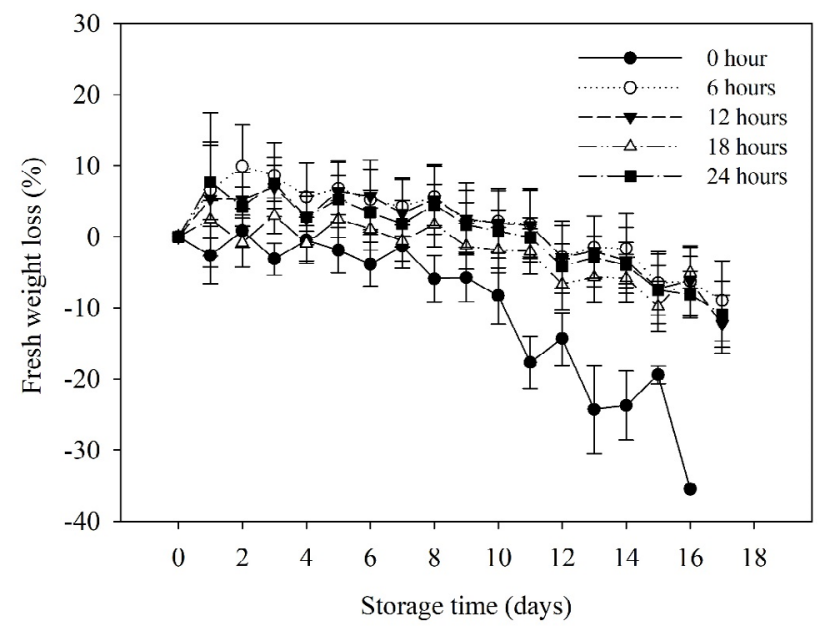

Figure 3. Fresh weight loss (\%) of Lilium pumilum flowers pulse-treated with sucrose (sucrose $20 \mathrm{~g} \mathrm{~L}^{-1}$ ), citric acid $\left(100 \mathrm{mg} \mathrm{L}^{-1}\right)$ and STS $(0.2 \mathrm{mM})$ at different times.

Data represent the mean \pm standard error $(n=4)$.

Table 2. Leaf relative water content (\%) of Lilium pumilum flowers pulse-treated with sucrose $\left(20 \mathrm{~g} \mathrm{~L}^{-1}\right)$, citric acid $\left(100 \mathrm{mg} \mathrm{L}^{-1}\right)$ and silver thiosulfate $(0.2 \mathrm{mM})$ for $0,6,12,18$ and $24 \mathrm{~h}^{*}$.

\begin{tabular}{lccccc} 
Pulsing time & After pulsing & Day 3 & Day $\mathbf{6}$ & Day 9 & Day 12 \\
0 hour & $90.6 \pm 0.5 \mathrm{Aa}$ & $84.1 \pm 1.4 \mathrm{Ab}$ & $82.6 \pm 0.7 \mathrm{Ab}$ & $84.7 \pm 1.5 \mathrm{ABb}$ & $85.9 \pm 0.0 \mathrm{Aab}$ \\
\hline $6 \mathrm{~h}$ & $85.7 \pm 5.0 \mathrm{Aa}$ & $90.5 \pm 1.1 \mathrm{Aa}$ & $81.0 \pm 4.8 \mathrm{Aa}$ & $80.3 \pm 1.8 \mathrm{Ba}$ & $90.5 \pm 0.9 \mathrm{Aa}$ \\
$12 \mathrm{~h}$ & $90.8 \pm 3.6 \mathrm{Aa}$ & $89.4 \pm 2.8 \mathrm{Aa}$ & $82.8 \pm 2.1 \mathrm{Aa}$ & $85.2 \pm 1.0 \mathrm{Aba}$ & $85.4 \pm 1.8 \mathrm{Aa}$ \\
$18 \mathrm{~h}$ & $77.0 \pm 0.7 \mathrm{Ac}$ & $94.3 \pm 3.5 \mathrm{Aa}$ & $83.2 \pm 2.1 \mathrm{Abc}$ & $88.1 \pm 1.5 \mathrm{Aab}$ & $86.0 \pm 2.5 \mathrm{Aabc}$ \\
$24 \mathrm{~h}$ & $85.0 \pm 1.1 \mathrm{Aa}$ & $89.2 \pm 1.5 \mathrm{Aa}$ & $86.5 \pm 2.6 \mathrm{Aa}$ & $86.3 \pm 1.8 \mathrm{Aba}$ & $83.1 \pm 3.5 \mathrm{Aa}$
\end{tabular}

*Means followed by the same uppercase letter in the column and lowercase letter in the row do not differ from each other by Tukey's test at $5 \%$ probability level. Data represents the mean \pm standard error $(n=4)$. 
Table 3. Anthocyanin content (mg $\left.100 \mathrm{~g}^{-1}\right)$ of Lilium pumilum flowers pulse-treated with sucrose $\left(20 \mathrm{~g} \mathrm{~L}^{-1}\right)$, citric acid (100 $\left.\mathrm{mg} \mathrm{L}^{-1}\right)$ and silver thiosulfate $(0.2 \mathrm{mM})$ for $0,6,12,18$ and $24 \mathrm{~h}$.

\begin{tabular}{|lccccc} 
Pulsing time & Day 0 & Day 3 & Day 6 & Day 9 & Day 12 \\
\hline 0 hour & $5.3 \pm 0.5 \mathrm{~A}$ & $7.7 \pm 1.3 \mathrm{~A}$ & $4.9 \pm 0.4 \mathrm{~A}$ & $9.3 \pm 0.7 \mathrm{AB}$ & $9.3 \pm 0.0 \mathrm{~A}$ \\
$6 \mathrm{~h}$ & $9.7 \pm 1.4 \mathrm{~A}$ & $5.8 \pm 0.7 \mathrm{AB}$ & $5.2 \pm 0.9 \mathrm{~A}$ & $7.0 \pm 0.7 \mathrm{~B}$ & $7.9 \pm 0.7 \mathrm{AB}$ \\
$12 \mathrm{~h}$ & $6.7 \pm 0.4 \mathrm{~A}$ & $5.8 \pm 0.5 \mathrm{AB}$ & $6.0 \pm 0.2 \mathrm{~A}$ & $10.3 \pm 0.2 \mathrm{~A}$ & $7.7 \pm 0.8 \mathrm{AB}$ \\
$18 \mathrm{~h}$ & $8.4 \pm 1.4 \mathrm{~A}$ & $5.5 \pm 0.3 \mathrm{AB}$ & $5.8 \pm 0.4 \mathrm{~A}$ & $6.8 \pm 0.6 \mathrm{~B}$ & $5.9 \pm 0.3 \mathrm{~B}$ \\
\hline $24 \mathrm{~h}$ & $8.9 \pm 1.3 \mathrm{~A}$ & $4.5 \pm 0.2 \mathrm{~B}$ & $4.9 \pm 0.4 \mathrm{~A}$ & $6.5 \pm 0.8 \mathrm{~B}$ & $6.2 \pm 0.7 \mathrm{~B}$ \\
\hline
\end{tabular}

*Means followed by the same uppercase letters in the column do not differ by Tukey's test at $5 \%$ probability level. Data represents the mean \pm standard error $(n=4)$.

It is worth mentioning that the commercial value of ornamental plants is associated with flower coloration. The main characteristics considered by consumers when choosing and buying flowers are their color and appearance, and those with pink, red or orange coloration are very appreciated, such as lilies, which are available in a wide selection of colors. However, loss of coloration is a natural process during flower senescence and is related to pigments, especially anthocyanin. Indirectly, anthocyanins have a key role in attracting pollinators and dispersers, and are important for environmental adaptation (Du et al., 2018).

Regarding the anthocyanin content, it was observed that the longest pulsing time $(24 \mathrm{~h})$ caused a decrease in this factor at the 3rd (42\%) and 12th (33\%) day when compared to the control (Table 3 ). At 0 and 6 th day, there was no difference between treatments $(p<0.05)$. On the 9th day, the control was not different from the other treatments; however, the anthocyanin content of the flowers that were pulse-treated for $12 \mathrm{~h}$ presented better results than the other pulsing times. As the anthocyanins are flavonoids that present antioxidant activity and there was no intense external stress, the maintenance of the values just after pulsing (day 0) can be justified. The opposite occurs at the end of a life cycle, when the production of free radicals associated with aging/ senescence increases (Taiz et al., 2017).

\section{Conclusions}

Based on the results, it is recommended to pulse $L$. pumilum flowers for $6 \mathrm{~h}$ with vase solutions containing silver thiosulfate $(0.2 \mathrm{mM})$ combined with citric acid (100 $\left.\mathrm{mg} \mathrm{L}^{-1}\right)$ and sucrose $\left(20 \mathrm{~g} \mathrm{~L}^{-1}\right)$. This treatment promotes reduced weight loss, increases longevity and provides a longer vase life.

\section{Author contribuition}

MRK: Formal analysis, software, writing - review and editing. MNSS: Conceptualization, data curation, software, writing - review and editing. MMT: Data curation, methodology, validation. AMM: Project administration, supervision.

\section{Acknowledgements}

The authors acknowledge the National Council for Scientific and Technological Development (CNPq) and the Coordination for the Improvement of Higher Education Personnel (CAPES) for their financial support.

\section{References}

ALKAÇ, O.S.; ÖCALAN, O.N.; GÜNEŞ, M. The effect of some solutions on the vase life of star flowers. Ornamental Horticulture, v.26, n.4, p.607-613, 2020. https://doi. org/10.1590/2447-536x.v26i4.2184

ALKASIR, K.; HASSANI, R.N.; AZAR, A.M. Effects of silver nanoparticles (SNPs) pulsing treatment and sucrose holding on flower and leaf senescence of cut rose. Journal of Ornamental Plants, v.7, n.2, p.103-113, 2017.

ALMEIDA, E.F.A.; PAIVA, P.D.D.O.; LIMA, L.C.D.O.; SILVA, F.C.; FONSECA, J.; NOGUEIRA, D.A. Calla lily inflorescences postharvest: pulsing with different sucrose concentrations and storage conditions. Ciência e Agrotecnologia, v.35, n.4, p.657-663, 2011. http://dx.doi. org/10.1590/S1413-70542011000400003

AMIN, O.A. Effect of some chemical treatments on keeping quality and vase life of cut chrysanthemum flowers. Middle East Journal of Agriculture Research, v.6, n.1, p.208-220, 2017.

AZUMA, M.; ONOZAKI, T.; ICHIMURA, K. Difference of ethylene production and response to ethylene in cut flowers of dahlia(Dahlia variabilis) cultivars. Scientia Horticulturae, v.273, 109635, 2020. https://doi.org/10.1016/j.scienta.2020.109635

BARBOSA, J.G.; REJANE, A.; FINGER, F.L.; REIS, F.P. Longevidade de inflorescências de lírio em função do estádio de desenvolvimento do botão e do condicionamento em sacarose. Bioscience Journal, v.21, n.2, p.25-31, 2005.

BELLÉ, R.A.; MAINARDI, J.C.C.; MELLO, J.B.; ZACHET, D. Abertura floral de Dendranthema grandiflora Tzvelev. 'Bronze Repin após armazenamento a frio 
seguido de "pulsing". Ciência Rural, v.34, n.1, p.63-70, 2004. https://doi.org/10.1590/S0103-84782004000100010

CATSKY, J. Water content. SLAVIK, B. Methods of studying plant water relations. Berlin: Springer, 1974. p.121-131.

DAR, R.A.; TAHIR, I. Effect of ethylene antagonist silver thiosulphate on the flower longevity of Clarkia pulchella Pursh. Journal of Horticultural Research, v.26, n. 1, p.512, 2018. https://doi.org/10.2478/johr-2018-0001

DIAS-TAGLIACOZZO, G.M.; GONÇALVEZ, C.; CASTRO, C.E.F. Manutenção da qualidade pós-colheita de lírio. Ornamental Horticulture, v.11, n.1, p.29-34, 2005. https://doi.org/10.14295/rbho.v11i1.20

DU, H.; LAI, L.; WANG, F.; SUN, W.; ZHANG, L.; LI, X.; WANG, L.; JIANG, L.; ZHENG, Y. Characterisation of flower colouration in 30 Rhododendron species via anthocyanin and flavonol identification and quantitative traits. Plant Biology, v.20, n.1, p.121-129, 2018. https:// doi.org/10.1111/plb.12649

FERREIRA, D.F. Sisvar: a computer analysis system to fixed effects split plot type designs. Revista Brasileira de Biometria, v.37, n.4, p.29-535, 2019. https://doi. org/10.28951/rbb.v37i4.450

FU, Y.; YANG, L.; GAO, H.; WENJI, X.; LI, Q.; LI, H.; GAO, J. Comparative transcriptome analysis reveals heat stress-responsive genes and their signalling pathways in lilies (Lilium longiflorum vs. Lilium distichum). PLoS One, v.15, n.10, e0239605, 2020. https://doi. org/10.1371/journal.pone.0239605

FULEKI, T.; FRANCIS, F. Quantitative methods for anthocyanins. 1. Extraction and determination of total anthocyanins in cranberries. Journal of Food Science, v.33, n.1, p.72-77, 1968. https://doi. org/10.1111/j.1365-2621.1968.tb00887.x

GUPTA, J.; DUBEY, R.K. Factors affecting postharvest life of flower crops. International Journal of Current Microbiology and Applied Sciences, v.7, n.1, p. 548-557, 2018. https://doi.org/10.20546/ ijcmas.2018.701.065

HUMMEL, M.; MIGUEL, L.A.P. Gerando valor na cadeia de flores de corte no mercado brasileiro. Prática em Contabilidade e Gestão, v.5, n.1, p.176-191, 2017. http:// dx.doi.org/10.5935/2319-0485/praticas.v5n1p176-191

LIMA, P.C.C.; RIBEIRO, W.S.; OLIVEIRA, M.M.T.D.; COSTA, L.C.D.; FINGER, F.L. Ethylene, 1-methylcyclopropene and silver thiosulfate on the post-production of ornamental pepper. Ciência Rural, v.47, n.2, p.1-8, 2017. https://doi.org/10.1590/01038478 cr20151611
LIU, J.; RATNAYAKE, K.; JOYCE, D.C.; HE, S.; ZHANG, Z. Effects of three different nano-silver formulations on cut Acacia holosericea vase life. Postharvest Biology and Technology, v.66, p.8-15, 2012. https://doi.org/10.1016/j.postharvbio.2011.11.005

LIU, J.; ZHANG, Z.; LI, H.; LIN, X.; LIN, S.; JOYCE, D.C.; HE, S. Alleviation of effects of exogenous ethylene on cut 'Master' carnation flowers with nanosilver and silver thiosulfate. Postharvest Biology and Technology, v.143, p.86-91, 2018. https://doi. org/10.1016/j.postharvbio.2018.04.017

MENEGAES, J.F.; LIDÓRIO, H.F.; BELLÉ, R.A.; LOPES, S.J.; BACKES, F.A.A.L.; NUNES, U.R. Postharvest of safflower flower stems harvested at different times and submitted to different preservative solutions. Ornamental Horticulture, v.25, n.1, p.87-96, 2019. http://dx.doi.org/10.14295/oh.v25i1.1989

MOURA, M.A.; MAPELI, A.M.; FINGER, F.L.; BARBOSA, J.G. Vida de vaso de inflorescências de Epidendrum ibaguense Kunth tratadas com inibidores de etileno. Revista Brasileira de Horticultura Ornamental, v.16, n.2, p.146-152, 2010. https://doi. org/10.14295/rbho.v16i2.555

NASCIMENTO, Â.M.P.D.; PAIVA, P.D.D.O; MANFREDINI, G.M.; SALES, T.S. Harvest stages and pulsing in ornamental sunflower 'Sunbright Supreme'. Ornamental Horticulture, v.25, n.2, p.149-157, 2019. http://dx.doi.org/10.14295/oh.v25i2.1991

PIVETTA, K.F.L.; MATTIUZ, C.F.M.; MELO, R.F.D.; GIMENES, R.; ROMANI, G.D.N.; BATISTA, G.S. Postharvest quality of Aster ericoides after treatment with silver thiosulphate and sucrose. Ciência Rural, v.48, n.12, p.1-8, 2018. https://doi.org/10.1590/0103$8478 \mathrm{cr} 20170349$

SALES, T.S.; PAIVA, P.D.O.; SIQUEIRA, H.H.D.; MANFREDINI, G.M.; LIMA, L.C.D.O. Preservative solutions on quality and biochemical aspects of calla lily flowers. Ciência e Agrotecnologia, v.42, n.2, p.176-185, 2018. http://dx.doi.org/10.1590/1413-70542018422020717

SANT'ANNA, H.L.S.; SANTOS, O.S.N.; SANTOS, C.R.S.; MARTINS, C.Y.; SANTOS, M.B.; ALMEIDA, M.A.; SILVA, F.; MARTINS, G.N.; LEDO, C.A.S. Longevidade pós-colheita de alpinia (Alpinia purpurata (Vieill) K. Schum) tratada com soluções de sacarose e extratos aquosos naturais. Revista Brasileira de Plantas Medicinais, v.12, n.3, p.269-277, 2010. http:// dx.doi.org/10.1590/S1516-05722010000300004

SANTOS, M.N.; MAPELI, A.M. Preservative solutions on conservation of cut lilies flower. Acta Horticulturae, v.1060, p.89-95, 2015. http://dx.doi.org/10.17660/ ActaHortic.2015.1060.11 
SANTOS, M.N.S.; TOLENTINO, M.M.; MAPELI, A.M. Vase life of cut Lilium pumilum inflorescences with salicylic acid. Ornamental Horticulture, v.24, n.1, p.44-49, 2018. https://doi.org/10.14295/ oh.v24i1.1148

SEDAGHATHOOR, S.; NAROUEI, Z.; SAJJADI, S.A.; PIRI, S. The effect of chemical treatments (silver thiosulfate and putrescine) on vase life and quality of cut Chrysanthemum morifolium (Ram.) flowers. Cogent Biology, v.6, n.1, 1754320, 2020. https://doi.org/10.1080/2 3312025.2020 .1754320

SIDHDHARTH, G.; NIVETHAA, P.J. Ethylene, Water and sugar-an influence in vase life of cut flowers. Biotica Research Today, v.2, n.12, p.1265-1267, 2020.
TAIZ, L.; ZEIGER, E.; MØLLER, I.M.; MURPHY, A. Senescência Vegetal e Morte Celular. In: TAIZ, L.; ZEIGER, E.; MØLLER, I.M.; MURPHY, A. Fisiologia e Desenvolvimento Vegetal. Porto Alegre: Artmed, 2017. p.666-692.

VAN DOORN, W.G. Role of carbohydrates in flower senescence: a survey. Acta Horticulturae, v.543, p.179-183, 2001. https://doi.org/10.17660/ ActaHortic.2001.543.21

ZHAO, D.; CHENG, M.; TANG, W.; LIU, D.; ZHOU, S.; MENG, J.; TAO, J. Nano-silver modifies the vase life of cut herbaceous peony (Paeonia lactiflora Pall.) flowers. Protoplasma, v.255, n.4, p.1001-1013, 2018. https://doi. org/10.1007/s00709-018-1209-1 